\title{
Rimpu: An Overview of Symbolic Meaning
}

\author{
1 Suryani Octavianingsih \\ ${ }^{1}$ Mataram University, Mataram, Indonesia \\ suryanioctavianingsih@gmail.com
}

\begin{tabular}{|c|c|}
\hline Article Info & Abstract \\
\hline $\begin{array}{l}\text { Article History } \\
\text { Received: July 12, } 2018 \\
\text { Accepted: September 30, } \\
2018 \\
\text { Keywords } \\
\text { Symbolic; Meaning; Rimpu; } \\
\text { Bima; Women }\end{array}$ & $\begin{array}{l}\text { This paper aims to describe the symbolic meaning of rimpu as a cultural } \\
\text { identity of female in Bima community. There are some meanings behind the } \\
\text { different ways of wearing rimpu between married and unmarried women. } \\
\text { Rimpu colo is worn by married women while rimpu mpida and rimpu cili are } \\
\text { worn by unmarried women. Data for this research were collected using } \\
\text { interview with Bimanese natives and library research to find the symbols of } \\
\text { the way of the rimpu is worn. The study found that there are special symbols } \\
\text { of rimpu for married and married women, including religious and cultural } \\
\text { symbols. Rimpu also indicates the woman's status in the society. }\end{array}$ \\
\hline $\begin{array}{l}\text { Support by: } \\
\text { do) Crossref }\end{array}$ & This is an open access article under the CC-BY-SA license \\
\hline
\end{tabular}

\section{INTRODUCTION}

Bima is located on the eastern cost of the island of Sumbawa in central Indonesia's province West Nusa Tenggara (NTB). It isone of the regions in NTB which is very popular for its religious society.Hilir Ismail (2004), a local historian states that Bimanese tribeis one of the many tribes in Indonesia which famously obedient toward the command of Islam. BahasaBima (Bimanese language) is the language which is used by people of Bima, which also called "Nggahi Mbojo", "Dou Mbojo" for Bimanese tribe and "Budaya Mbojo" for its culture.

In terms of culture, Bima is also known for its strong culture which shapes its own sketch of characteristic and identity. One of the cultures which reflect very much into the characteristic and identity of the Bimanese people is rimpu. Rimpu shares islamic values, belief, behavior in Bimaneseway of life, which is not easy affected by any kind of foreign culture and customs. Moreover, rimpu is a hereditary culture which has been proclaimed by the ancestors of Bimanese tribe as a Bimanese culture and identity since 1640, which is maintained and preserved until today.

According to Syaukani, a local historian of Bima, linguistically, rimpu in Bimanese language consists of two syllables, "ri" means return and "mpu" means cover. Thus, literally, the term rimpu is the clothes which cover the entire body of a woman using Bimanese typical woven sarong. Similarly, Hilir Ismail (2005) says that rimpu is traditional clothes of Bimanese female which use two sheets of sarong called "tembe nggoli", a typical weaving sarong originally from Bima. One sheet covers the head, and another sheet is worn as a skirt. In the other words, rimpu as the way of female dressing represents a cultural identity of the females in Bima community. Furthermore, rimpu has its own aesthetic value for the women since years ago. It is one of the beautiful clothes in terms of motives of sarong, materials and also the beauty and uniqueness of the way of rimpu is worn.

Furthermore, the way of wearing rimpu indicates the status of women in the society that rimpu for married women is very different from unmarried women. And this paper 
aims to describe the symbolic meaning behind the different ways of wearing rimpu between them. The methods used in the study are library research and interview with Bimanese native that described the symbolic meaning of the way of the rimpu is worn.

\section{METHOD}

Data for this research were collected using interview with Bimanese natives and library research to find the symbols of the way of the rimpu is worn.

\section{RESULT}

\section{The Short History of Rimpu}

Historically, the existence of Rimpu was along with the spread of Islam on 5 July 1640, coinciding with the 15th of RabiúlAwal 1050. At the time, the appearance of rimpu as a traditional customary clothing was to commemorate the development of Bimanese tradition which served as a basis of the emergence of Islam in Bima since the establishment of the sultanate, in which rimpu became the religious polarity of Bimanese in order to develop cultural tribes. According to Hilir (2004), a local historian, rimpu has been a part of the cultural identity of Bimanese female since Islam began to develop in Bima. He adds that at the time, wearing rimpu was to show that they could weave the clothes on their own.

Moreover, Arabian traders who came to Bima particularly Arabian women, became a big inspiration for Bimanese women to wear rimpu as their identity. In other hands, the existence of rimpu according to Hilir Ismail cannot be separated from the efforts of the government to exploit the Bimanese sarong and woven fabric with has been known to be a world's best-selling commodity around 13th century. At the time, Bimanese community utilized the abundance of cotton and processed them into woven fabric which then became a trade commodity which is also sold to China.

Fahru Rizki, a Bimanese native who previously conducted a study about rimpu says that rimpu is actually the way of Bimanese female wearing the woven sarong, not clothes of what people called today. By the time, the rimpu develops and spreads to other parts of Bima, people begin to know and call the rimpu as the traditional clothes and become the identity of the Bimanese people (interview, July 30th, 2018)

Before rimpu is popular in the community, the people of Bima have been acquainted with "katente" and "sanggentu". Katente is worn by male, by rolling up the sarong to the waist. Meanwhile, sanggentu is worn by rolling the sarong to the chest. Sanggentu is usually worn by woman. To this day, katente is still worn by the Bimanese men for certain religious events.In another part of Bima such as Donggo village, the women wear "kababu" for the upper clothing and "deko", a trouser covering with sarong which has a distinctive style and motifs for the down clothing (Ariadi, 2011).

Moreover, in another area of Bima such as Dompu, the women wear "baruko", a thin cloth to cover their head and face, only eyes appeared. The women in Dompu began to wear rimpu around 1990 as Fahru Rizki said

“Wanita Dompu mulai menggunakan rimpu sekitar tahun 1900. Awalnya kerudung wanita Dompu disebut Baruko, satu kain tipis dililitkan untuk menutup kepala, hanya bagian mata yang terlihat" (interview, 30/07/2018)

"Dompunese women began to wear rimpu around 1900. Previously, the veil of Dompunese women is called Baruko, a thin cloth which is wrapped around the head, left only eyes visible" (interview, 30/07/2018)

The following figure shows baruko worn by the Dompunese women in 1924. 


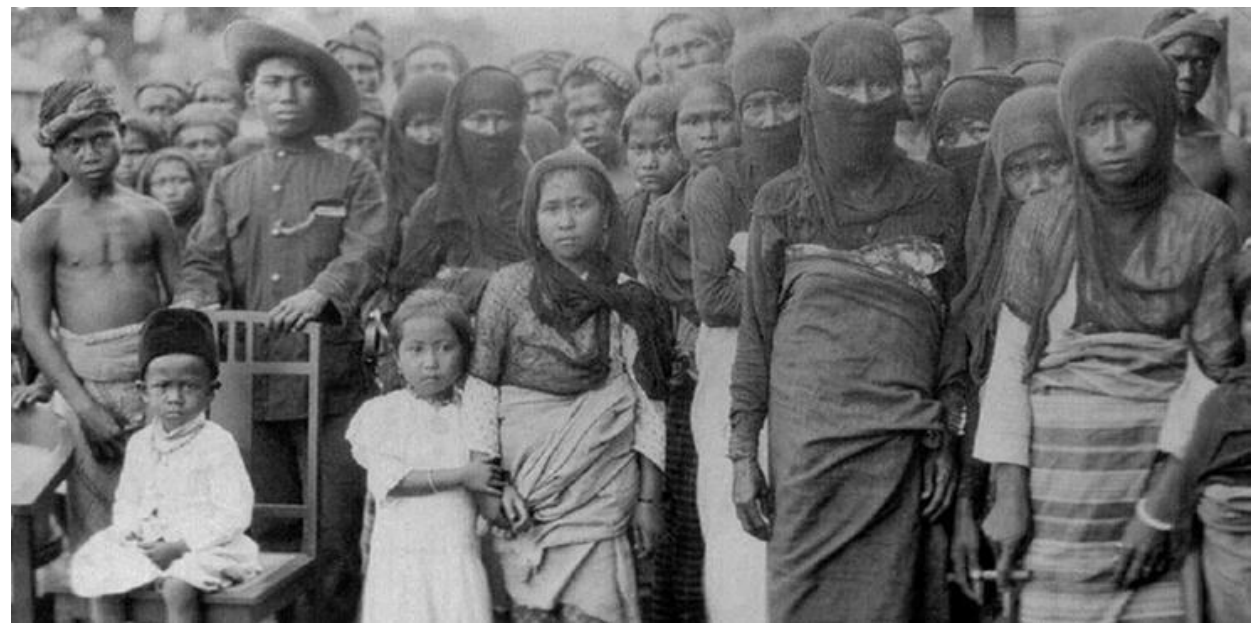

The figure is taken from unpublished article by Fahru Rizki

\section{Rimpu as The Implementation of The Religious Value}

The spread of Islamic value in Bima has been started since the establishment of sultanate in 1640. The strategy used to spread Islam at the time was by mixing the culture and tradition with the religious value of Islam. In other words, mixing and implementing Islamic values together with the culture and tradition seems to be better way for the government. And the strategy successfully introduces the Islamic values and was the successful achievement for the sultanate to spread Islam in Bima (Honest D. Molasy, 2011).

Moreover, since Islam spread and exist in Bima, the Islamic values influence the way of Bimanese people dressing. Women wear kababu. The kababu, a traditional clothis worn a little bit longer to cover the body. For the down clothing, they wear deko, a trouser and cover with weaving sarong. The women also wear "to'du", a traditional veil that people call rimpu until today (Honest D. Molasy, 2011).

As the traditional cloth which is affected by Islam, rimpu, however is not only a tradition of Bimanese community but also it comes as a manifestation to present religious values in the form of culture in daily lives of Bimanese people. For all of that, wearing rimpu is one of the cultural ways in attempting to implement the belief system and the religious values adopted by the Bimanese female community. Then, as one of the valuable cultures, rimpu is a visual representation of a woman's religious affiliation and appreciates the religious norms and values as the synergistically guidance to cover the woman's genitalia. In other words, as required to cover the entire body for women is also firmly stated in the holy book of Muslim (Quran), rimpu also comes to teach that every single woman is obliged to keep their honor and to cover their genitals or entire body, not to provoke the man in particular biological impulse fishing.

Thus, for the Bimanese people, rimpu is not only an accommodation of Islamic teachings, but also a local living tradition in the community which is strongly affiliated to Islamic religious as an expression of protection toward women. Moreover, the Bimanese slogan of "Mori ro made nadou Mbojo ede kai hukum Islam-ku" which means "Life and death of the Bimanese people should be based on the Islamic law" which has been upheld enables the Bimanese female to keep and manage their everyday behavior and mannerism from the things prohibited by the religion.

\section{Rimpu as Bimanese Cultural Identity}

Culture is not the thing that someone possessesit as individual phenomena. It is a product which originates and grows in the society then shared through social interaction as the continuous process, then becomes the characteristic and identity of 
the whole ways of life of the society at the end. Edward Tylor (2008) views certain essential aspects of culture. Firstly, culture is learned. It is acquired by learning, which implies that it is not genetically inherited. Secondly, culture is knowledge shared among members of a group. This implies that culture is transmitted between generations through the use of symbols, which lead to anthropological interest in language, indigenous systems of knowledge, and the processes of acquiring culture. Thirdly, culture is taken in its wide ethnographic sense, which is complex whole of human experience, which implies that cultureis not only limited to arts, beliefs, morals, law, costume, fashion, design and any other habits acquired by someone as a member of society, but also it encompasses the broad domain of human experience.

Cultural identity was first theorized by Marry Jane Collier and Milth Thomas (1988). They define cultural identity is the status, experience, enactment, creation, negotiation, and contestation of group membership and social identification within particular contexts. Collier (2005) broadens cultural identities to include cultural identifications as a move to locate oneself and one's identity positioning and alignments in complex cultural structures and dynamic relations with others. Conception of cultural identity conquers three core understandings. Firstly, cultural identity is simultaneously an individual entity, a social category, and then a system of communicative practice. Secondly, cultural identity is both an individual choice and group right. Thirdly, cultural identity is adaptive, evolving, flexible, negotiable or non-negotiable, distinct, communal, and discrete (Kim, 2007)

Thus, a traditional cloth of rimpuidentifies cultural society and provides the way intothe identity of the Bimanese women as self-presentation to express and perform the identity in daily lives of their social interactions as Fahru Rizki stated.

"Rimpu sangat sering dipakai oleh wanita jaman dulu, Mereka memakai rimpu untuk menunjukan identitas mereka bahwa mereka berasal dari Bima" (interview, 30/07/2018)

"Rimpu was frequently worn by old women, they wore rimpu was to show their identity that they were from Bima"(interview, 30/07/2018)

Furthermore, in the performing of the cultural identity, rimpu addresses a characteristic which distinguishes between the original cultural diversity owned with other regions in Indonesia. For instance,the pattern of Bimanese woven sarong and the way of the sarong is worn identifies its original culture comes from. In addition, rimpu isalso as a media of nonverbal communication for the wearer to communicate and bringherself as an individual and to communicate and define her social group identity that she belongs to.

\section{The Theory of Symbol}

Since culture is a measurement of human behavior and mannerism, a symbol can be viewed as a sign which is used to create and deliver a message and belief system adopted by the society. Similarly, the term of symbol comes from Greek, symboion as a means to deliver a message and to organize the epistemology and belief system. Peirce (1958) defines symbol as sign which refers to the object that it denotes by virtue of a law, usually an association of general ideas, which operates so that the symbol is interpreted as referring to that object. And the object according to Blummer(1962) has three classes; physical objects, social objects and abstract objects.

Furthermore,the theory of symbols also comes from Herbert Blumer (1962), originator of the term "symbolic interactionism" explains that symbolic interaction points to characteristic of humans' interaction that they mutuallyrespond and interpret each other's action. Moreover, a person's response is not directly made to other's actions but based on the meaning given to the action of the others. Interaction between 
individuals is mediated by the use of symbols, interpretation or by trying to interpret and understand each other's actions.

Blumer (1962)further describes his discipline and sets into three premises. Firstly, people act toward things based on the implications those things have for them. Secondly, such implications emerge out of the interaction of the person with others. Thirdly, an interpretive process is utilized by the individual in each occasion in which he should manage things in his environment. However, symbolic interactionism holds the view that the focal part in human conduct has a place with these exceptionally implications which different perspectives would reject as coincidental (Herbert Blumer, 1962)

As human beings who live in community, we use symbol to reveal who we are and to understand and interpret each other's interactions. In certain social settings, symbols give people to connect with the social world, create categories, and recall the objects they find wherever they are. Symbols perfectly complete people to understand their environments. Symbols enhance the human beings' ability to think as a symbolic interaction. Moreover, symbols increase the human's ability to solve human's problem by using the symbols to overcome those problems.

Thus, in terms of symbolic interactionism described by Herbert Blumer, rimpu as it essentially has exclusive culture as a symbol and has meaning behind every single way of the rimpu worn by woman, seems tobe inextricably connected to the issue of the symbol used in social interaction in the form of culture in many ways of social settings in Bima community. Moreover, in the form of rimpu, Bimanese women define themselves and the world around them through their symbolic interactions with one another.

\section{The Symbolic Meaning of Rimpu}

As previously explained that rimpuhas become the cultural identity of Bimanese especially for Bimanese women. In the style of wearing, rimpuhas different symbolic meaning behind the different ways ofrimpu worn by married and unmarried women. Rimpu worn by unmarriend woman is divided into two styles.

1. Rimpu Cili

Rimpucili is worn by using two sheets of Bimanese sarong to cover the entire body, head and face. An opening is left only for a narrow slit for the eyes. Another sheet of sarong is usually worn as a skirt(Ulya, 2017). This rimpu is worn by unmarried woman or girl that is going to be a bride. The symbolic meaning behind of the way of wearing this rimpu is to tell the society that the girl has been purposed by a man. Moreover, the symbol of the rimpu may also be said thatsince the girl is already purposed, she isnot allowed to have any interaction with other men. The girl has to wear this style of rimpu since the first day of the proposal until she is married.

2. Rimpu Mpida

Rimpumpida is slighly the same as the way rimpucili is worn. Rimpumpida only leaves eyes and nose. This rimpu is most commonly worn by the girls or unmarried women (Ulya, 2017). The rimpumpida symbolizes that the girls are still single and they have not been proposed or married by any men. In addition, at this phase, since the girls have not been proposed yet, they are banned to show their face until the men come to purpose. Nevertheless, their activities and movements are not restricted. The women have to wear this style of rimpu until they are purposed. The following figure shows rimpucili and rimpumpida worn by the girl or unmarried woman. 


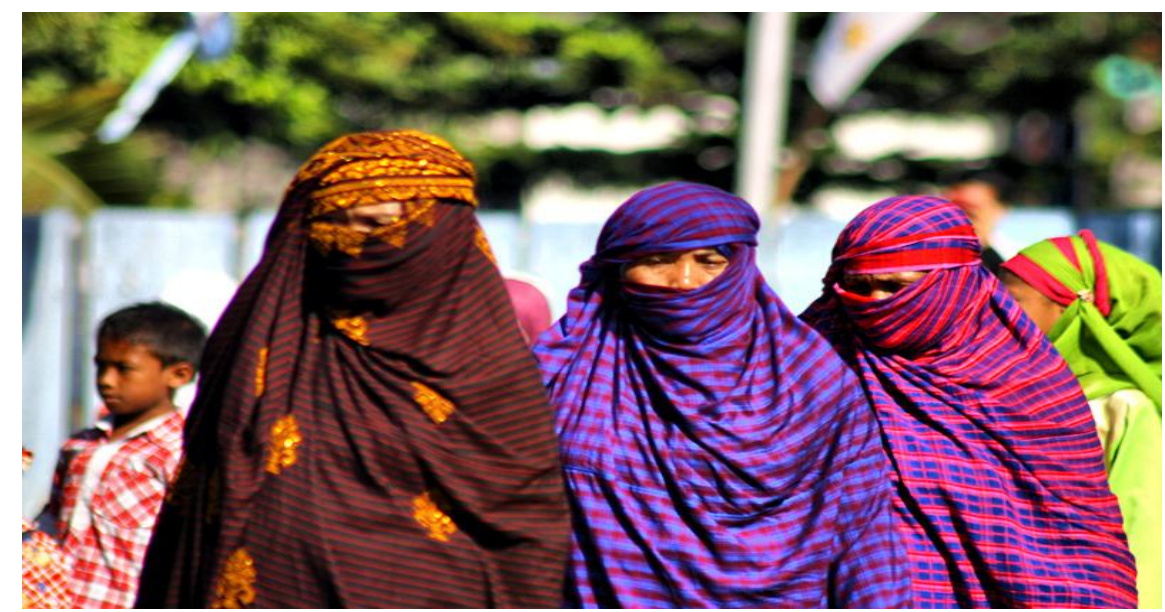

However, rimpu which is worn by married women called rimpucolo. The rimpucoloconsists of two sheets of Bimanese sarong that one sheet covers the head and neck, an opening is left for face. Another sheet is also worn as a skirt (Ulya, 2017). This rimpu is commonly worn by married women or housewives (Hilir, 2004).The symbolic meaning of the way of wearing this style of rimpu is to indicate the women's social status and indirectly introduces themselves as married women in the society. Moreover, the tolerance for the married women to show their face in their daily social interactions is also symbolized through rimpucolo as Fahru Rizki stated

"Rimpucili, rimpumpida dan rimpucolo sebenarnya menunjukkan status si pemakai. Rimpucili dan rimpumpida dipakai oleh gadis-gadis atau wanita-wanita yang belum menikah sedangkan rimpucolo dipakai oleh wanita yang sudah menikah (interview, 30/07/2018)"

("Rimpucili, rimpumpida and rimpucolo are actually to show the social status of the wearers. Rimpucili and rimpumpida are worn by girls or unmarried women. Meanwhile, rimpucolo is worn by married women.") (interview, 30/07/2018). The following figure shows rimpucolo worn by unmarried women or housewives.

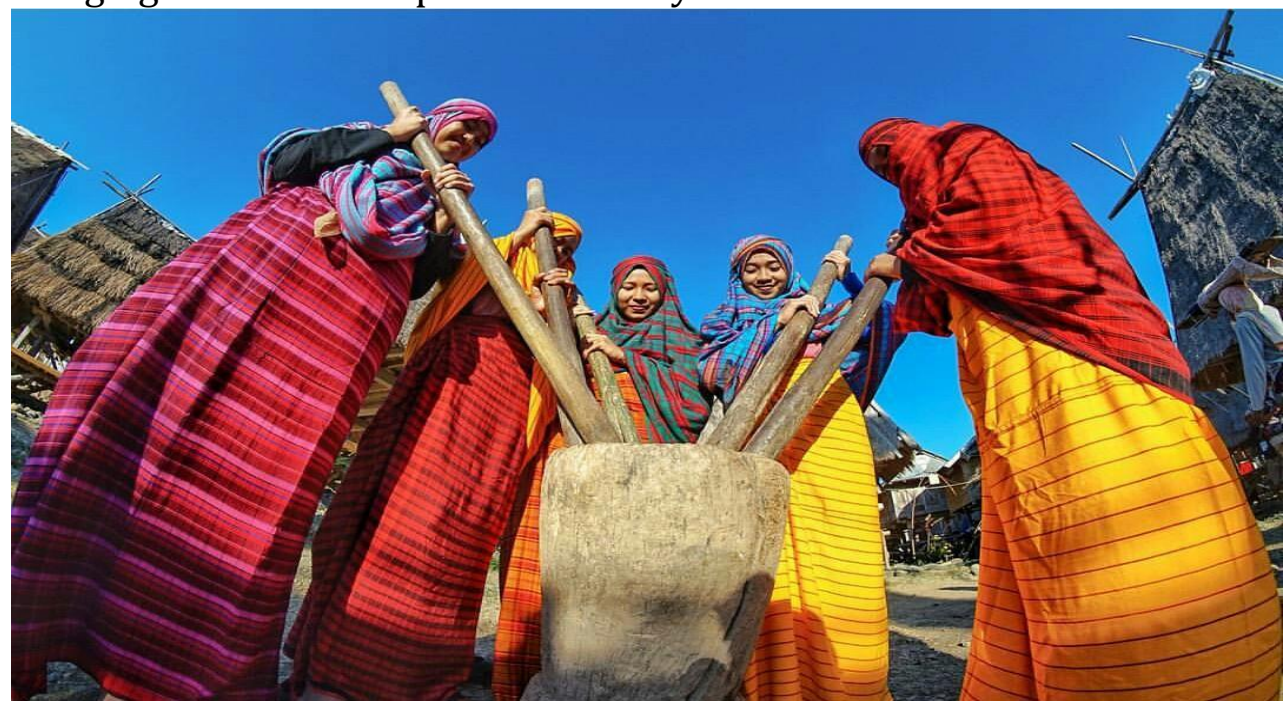

Furthermore, it is said that, the different style of rimpu worn by married and unmarried women represents the women's reputation in the society, and it distinguishes between married and unmarried women; their marital status can be seen from the way the women wear their rimpu. A man could automatically find his mate based on the style of rimpumpida worn by a woman. Meanwhile, the rimpucolo which is 
previously explained represents the married status of the woman. The man will directly recognize that the woman with this style of rimpu is already married (Ariadi M. L, 2011)

Moreover, the pattern and the color of the sarong do not indicate the woman's social status. In other words, there is no particular pattern and color of the sarong worn by married and unmarried woman to symbolize their status in the society as a Bimanese native, Fahru Rizki said.

"Pemakaian rimpu sendiri tidak membedakan motif dan warna sarung untuk wanita yang belum menikahdan yang sudah menikah. Sarung apapun tidak ada bedanya. Yang beda hanya nama sarungnya, yaitu"tembecau"dan"tembenggoli". Dulu sarung yang tidak bermotif dipakai oleh masyarakat biasa sedangkan sarung yang bermotif hanya dipakai oleh kalangan bangsawan. Tapi sekarang sudah tidak membedakan motif dan warna yang harus dipakai oleh wanita yang belum menikah dan wanita yang sudah menikah." (interview, 30/07/2018)

("Rimpu does not differentiate the pattern and color of the sarong for married and unmarried woman. They can wear any kind of sarong. The only difference is the name of sarong that is "tembecau" and "tembenggoli". In the past time, the sarong which has no pattern is only worn by commoners. Meanwhile, the sarong which has pattern is worn by noble families. But today, there is no particular motive and color of the sarong that should be worn by married and unmarried woman.") (interview, July 30th, 2018)

Rizki also adds that in the past time, the Bimanese people particularly in Malay (Kampung Melayu), wore only one color of sarong that is grey or orange. Since the culture of rimpu is acculturated and developed, rimpu then comes.

\section{CONCLUTION}

Rimpu grows naturally as local cultural creativity and tradition of the Bimanese women. The fundamental value of rimpu for Bimanese women is politeness and identity. The women cover their entire body tightly with the creativity of rimpu they created themselves. They wave sarong on their own and wear the sarong as their identity. As rimpu takes a special symbolic meaning in the way it is worn, rimpu defines and marks a woman's social status as an individual, then defines and introduces the woman's social group identity as a member of the community. Furthermore, to identify the difference social status of the women in the community,an unmarried woman who has been proposed will wearrimpucili. Meanwhile, other unmarried womenwill wear rimpumpida. The married women or housewives will wear rimpucolo.At the recent years, the Bimanese women who wear rimpu can be found in certain areas of Bima such as Wawo, Sape, Lambitu, woha, Monta, Sanggar and Tambora.

However, the religious values and practice of rimpu in Bimanese female community can be presented as the concept of Islamic tourism to attract the Muslim tourists around the world since West Nusa Tenggara wins world's halal tourism awards and continues to improve to become a center of world's halal tourism.

Lastly, this study is hopefully expected to present reference and to provide ideas for other writers to conduct further studies on rimpu or on other local cultures and traditions of the Bimanese people.

\section{REFERENCE}

[1] Ariadi M. Lalu. 2011.Manuscripts and Acculturation of Syariah Values in Indonesia Islamic Civilization. Annual International Conference on Islamic Studies. 
[2] Berger M. Bennet. 1995. An essay on culture: Symbolic structure and social structure. Los Angeles: University of California Press.

[3] Cownie Fiona. 2004. Legal Academic: Culture and Identity. Oregon: Hart Publishing.

[4] Aulia N. Rihlah. 2013. Rimpu: Budaya dalam Dimensi Busana Bercadar Perempuan Bima. Universitas Negeri Jakarta.

[5] Collier, M.J., \& Thomas, M. 1988. Identity in intercultural communication: An interpretive perspective. Newbury Park, CA: SAGE.

[6] Hilir M. Ismail. 2004.Peran Kesultanan Bima dalam Perjalanan Sejarah Nusantara. Mataram: Penerbit Lengge,

[7] Hilir M. Ismail. 2005. Sejarah Kebudayan Masyarakat Bima. Mataram: Lengge Press.

[8] Kim, Y. Y. 2007. Ideology and intercultural communication: an analysis of differing academic conception of cultural identity. Journal of Intercultural Communication Research.

[9] Jerry D. Moore. 2009. Visions of Culture: An Annotated Reader. New York: Rowman \& Littlefield.

[10] Ulya K. Nurul. 2017. Resepsi Konsep Menutup Aurat dalam Tradisi Pemakaian Rimpu. UIN Sunan Gunung Djati, Bandung.

[11] https://www.researchgate.net/publication/319260864._The_symbol_theory_in_ S_Freud_C_G_Jung_and_C_S_Peirce [accessed Jul 23 2018]. 